\title{
URGENSI PENDIDIKAN AGAMA ISLAM \\ DALAM PENGEMBANGAN NILAI-NILAI MULTIKULTURAL
}

\author{
Salmiwati \\ Dosen Fakultas Tarbiyah dan Keguruan IAIN Imam Bonjol Padang \\ e-mail: salmiwati@yahoo.co.id
}

\begin{abstract}
The function of Islamic education as one of compulsory subjects is to form the students' character in order to be obedience and tolerance muslims. Thus, they can accept multicultural system and reject any form of oppresses because of diversity. It can be specifically seen from the objective of the lesson which aims to create Indonesian citizens to be diligent worshipers, good, knowledge, intelligent, honest, wise, discipline, and tolerance muslims. They also should keep the harmony and develop religion and culture in the schools.
\end{abstract}

Key words: Islamic education, multicultural

\begin{abstract}
Abstrak: Fungsi Pendidikan Agama Islam sebagai mata pelajaran yang masih dipertahankan dalam Sistem Pendidikan Nasional diharapkan mampu membentuk karakter peserta didik, sehingga menjadi manusia muslim yang bertaqwa (dalam arti taat kepada Allah SWT.) dan sekaligus menjadi warga negara Indonesia yang toleran, menerima kondisi multi kultural, serta menolak segala bentuk penindasan yang merendahkan harkat kemanusiaan karena perbedaan itu. Hal ini secara spesifik dapat dilihat dari tujuan pembelajaran, yakni mewujudkan manusia Indonesia yang taat beragama, berakhlak mulia yaitu manusia yang berpengetahuan, rajin beribadah, cerdas, produktif, jujur, adil, etis, berdisiplin, bertoleransi (tasamuh), menjaga keharmonisan secara serta mengembangkan budaya agama dalam komunitas sekolah.
\end{abstract}

Kata kunci: Pendidikan Agama Islam, multikultural

\section{PENDAHULUAN}

Indonesia adalah bangsa yang majemuk, bahkan Indonesia adalah salah satu negara multikultural terbesar di dunia. Multikulturalitas bangsa Indonesia ini dapat dibedakan menjadi dua, yaitu perbedaan vertikal dan perbedaan horizontal. Perbedaan vertikal ditandai dengan realitas adanya pelapisan sosial atas bawah dalam struktur kemasyarakatan sebagai akibat perbedaan masing-masing individu di bidang politik, ekonomi, sosial dan pendidikan. Sedangkan perbedaan horizontal adalah perbedaan masyarakat berdasarkan kesatuan sosial, budaya, suku, ras, bahasa, adat istiadat, dan agama.

Multikulturalitas bangsa Indonesia ini bisa diibaratkan pisau bermata ganda. Di satu sisi bisa menjadi potensi yang berharga dalam membangun peradaban bangsa, di sisi lain apabila tidak dapat dikelola dengan baik, multikulturalitas tersebut akan memunculkan konflik yang mampu menghancurkan sendisendi kehidupan berbangsa dan bernegara bahkan disintegrasi bangsa. Perbedaanperbedaan tersebut akan menjadi beban atau kekayaan tergantung bagaimana cara mengolahnya. (Said Agil Husin al-Munawar, 2003: 213).

Kenyataan bahwa dalam kehidupan masyarakat yang plural, seringkali terjadi konflik yang pada akhirnya akan menyebabkan terganggunya stabilitas dan ketidakharmonisan. Di Indonesia seringkali muncul fenomena kekerasan seperti konflik etnis, konflik antar umat beragama, dan konflik lainnya. Salah satu contoh masalah yang dapat kita temui dalam kehidupan beragama yang plural ini adalah kecurigaan dan kesalahpahaman dari satu penganut agama terhadap sikap dan perilaku 
agama lain, bahkan juga terhadap sesama penganut agama tertentu.

Bangsa ini tidak boleh dibiarkan terkoyakkoyak atau terpecah-pecah, harus ada usaha untuk menumbuhkan kembali semangat persatuan dan kesatuan yang dulu menjadi modal penting untuk merebut kemerdekaan dari tangan penjajah. Harus mulai menanamkan prinsip-prinsip saling menghormati baik dari sisi agama, budaya, etnis maupun bahasa untuk bisa hidup saling berdampingan secara damai. Prinsip ini mesti ditanamkan sejak dini, salah satunya melalui pendidikan agama --termasuk Pendidikan Agama Islam--

Permasalahan pokok yang dihadapi pendidik pada era multikultural adalah bagaimana agar masing-masing penganut suatu agama tetap dapat mengawetkan, melanggengkan, mengalihgenerasikan, serta mewariskan kepercayaan yang diyakininya sebagai suatu kebenaran yang mutlak, namun pada saat yang sama juga menyadari sepenuhnya keberadaan agama lain yang juga berbuat serupa. (M. Amin Abdullah, 2005: 3) Maka dalam hal ini Pendidikan Agama Islam bisa memberikan kontribusinya dalam pengembangan nilai-nilai multikultural.

Tulisan ini membahas bagaimana peran Pendidikan Agama Islam dalam pengembangan nilai-nilai multikultural.

\section{PENGERTIAN MULTIKULTURALISME DAN PENDIDIKAN MULTIKULTURAL}

Secara etimologi, multikulturalisme dibentuk dari kata multi (banyak), kultur (budaya), dan isme (aliran/paham). Secara hakiki, dalam kata itu terkandung pengakuan akan martabat manusia yang hidup dalam komunitasnya dengan kebudayaannya masingmasing yang unik. (Choirul Mahfud, 2006: 75) Sedangkan kultur itu sendiri tidak bisa terlepas dari empat tema penting yaitu: agama (aliran), ras (etnis), suku, dan budaya. (Ain al-Rafiq Dawam, 2003: 99-100) Multikulturalisme secara filosofis pada dasarnya merupakan pandangan yang meyakini bahwa dalam realitas kehidupan terdapat keragaman (diversity) atau kemajemukan (plurality) kebangsaan, ras, suku, bahasa, tradisi, agama, kepentingan dan sebagainya yang harus dihormati diakui, atau difungsikan. (Choirul Fuad Yusuf, 2006: 21).

Abdul Munir Mulkhan mengemukakan bahwa multikulturalisme adalah gagasan yang lahir dari fakta tentang perbedaan antar warga masyarakat bersumber etnisitas bersama kelahiran sejarah. (Abdul Munir Mulkhan, 2005:7) Multikulturalisme sebenarnya merupakan konsep di mana sebuah komunitas dalam konteks kebangsaan dapat mengakui keberagamaan, perbedaan dan kemajemukan budaya, baik ras, suku, etnis, dan agama. Sebuah konsep yang memberikan pemahaman kita bahwa sebuah bangsa yang plural atau majemuk adalah bangsa yang dipenuhi dengan budaya-budaya yang beragam atau multikultur. Bangsa yang multikultur adalah bangsa yang terdiri dari kelompok-kelompok etnik atau budaya yang ada dapat hidup berdampingan secara damai dalam prinsip co-existence yang ditandai oleh kesediaan untuk menghormati budaya lain. (Nanih Mahendrawati dan Ahmad Syafe'i, 2001: 34).

Dengan demikian paradigma multikultural memberi pelajaran kepada kita untuk memiliki apresiasi dan respek terhadap budaya dan agama-agama lain. Atas dasar ini maka penerapan multikulturalisme menuntut kesadaran dari masing-masing budaya lokal untuk saling mengakui dan menghormati keanekaragaman identitas budaya yang dibalut semangat kerukunan dan perdamaian. Diharapkan dengan kesadaran dan kepekaan terhadap kenyataan kemajemukan, pluralitas bangsa, baik dalam etnis, agama, budaya hingga orientasi politik, akan bisa mereduksi berbagai potensi yang dapat memicu konflik sosial di belakang hari.

Pendidikan multikultural merupa-kan suatu wacana yang lintas batas, karena terkait dengan masalah-masalah keadilan sosial (social justice), demokrasi dan hak asasi manusia. (H.A.R Tilaar, 2003:167) Azyumardi azra mende-finisikan pendidikan multikultural sebagai pendidikan untuk atau tentang keragaman kebudayaan dalam merespon perubahan demografi dan kultur lingkungan masyarakat tertentu atau bahkan demi secara keseluruhan. (Mashadi 
Imron, 2009: 48) Prudence Crandall mengemukakan bahwa pendidikan multikultural adalah pendidikan yang memperhatikan secara sungguh-sungguh terhadap latar belakang peserta didik baik dari aspek keragaman suku (etnis), ras, agama (aliran kepercayaan) dan budaya (kultur). Secara lebih singkat Andersen dan Custer (1994) mengatakan bahwa pendidikan multikultural adalah pedidikan mengenai keragaman budaya. (H.A Dardi Hasyim, 2009: 28) Sedangkan Musa Asy'ari juga menyatakan bahwa pendidikan multikultural adalah proses penanaman cara hidup menghormati, tulus, dan toleran terhadap keanekaragaman budaya yang hidup di tengahtengah masyarakat plural. Musa Asy'arie, http://www.kompas.com/kompas-cetak/ 0409/ 03/opini/1246546

Maka pendidikan multikultural sangat penting diimplementasikan dalam pendidikan Nasional, dan dianggap sebagai perekat utama dalam mewujudkan keutuhan Negara Kesatuan Republik Indonesia. Indonesia sebagai bangsa yang majemuk terdiri dari berbagai suku, agama, ras (etnik), dan golongan. Hal ini bisa menjadi potensi konflik yang dapat mengganggu kestabilan politik dan menghambat pembangunan bangsa. Akan tetapi di dalam adat istiadat suku bangsa dan di dalam ajaran-ajaran agama itu terkandung pola potensi dan modal kedamaian. Islam adalah agama yang mengajarkan kedamaian, toleransi, kebersamaan (egalitarianisme) dan menghargai perbedaan. Dalam ajaran al-Quran perbedaan itu adalah kudrat Ilahi yang wajib disyukuri, dan setiap orang dituntut agar menghormati kebinekaan tersebut.

\section{NILAI-NILAI PLURALIS MULTIKUL- TURAL DALAM AJARAN ISLAM}

Islam sebagai suatu perangkat ajaran dan nilai, meletakkan konsep dan doktrin yang merupakan rahmat li al-'alamin. Sebagai ajaran yang memuat nilai-nilai normatif, maka Islam sarat dengan ajaran yang menghargai dimensi pluralis-multikultural. Begitu bagus dan indahnya Islam dalam memandang dan menempatkan martabat dan harkat manusia, baik sebagai makhluk individu maupun sebagai anggota sosial.

Dalam al-Quran dijelaskan tentang kewajiban seorang muslim untuk menjadi juru damai, yaitu senantiasa menjaga kedamaian dan kerukunan hidup dalam lingkungannya. Sebagaimana firman Allah:

* w u ö yz îu 9 ÏV 2 "̈̈iB öNßgluqôf ${ }^{-R}$ wî) ô‘b t tBr\& >ps\% |Áî/ $\div r$ \& $>\$ r a ̃ \quad \div$ èt $\left.B \div r r \& \notin x » n=0{ }^{11}\right) \quad u ́ \div u ̈ t /$

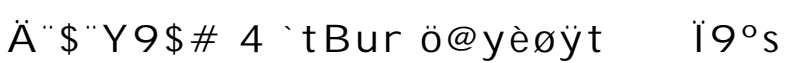
uä!\$tóïFö/ \$\# ÏN\$|Éó sD «!\$ t\$öqlisù Ïm Ï? ‘sçR \#· ô_r\& \$\K Ïàtã ÇÊẾít

"Tidak ada kebaikan pada kebanyakan bisikanbisikan mereka, kecuali menyuruh (manusia) memberi sedekah, berbuat ma'ruf (baik), atau melakukan islah (perdamaian) di antara manusia”. Kewajiban ini tidak hanya ditujukan kepada saudara seagama saja, sebab Allah SWT, secara tegas menyatakan bahwa manusia berasal dari seorang laki-laki (Adam) dan seorang perempuan (Hawa), sehingga mereka semua bersaudara.(Q.S. Al-Nisa: 114)

Lebih jauh, ajaran Islam juga mewajibkan umatnya mencegah segala bentuk penganiayaan yang hendak dilakukan oleh "saudaranya" kepada "saudaranya" yang lain. Sebagaimana termaktub dalam hadits Rasul:

“Tolonglah saudaramu, baik ia berlaku aniaya maupun teraniaya. Seorang sahabat bertanya, wahai Rasulullah, kami pasti akan menolongnya jika ia teraniaya, akan tetapi bagaimana kami menolongnya jika ia berlaku aniaya?, Nabi menjawab: Halangi dan cegahlah dia agar tidak berbuat aniaya. Yang demikian itulah pertolongan baginya”. (HR Bukhori).

Demikian agungnya ajaran Islam, sehingga sebenarnya jika seorang muslim mau bersungguh dalam mempelajari dan mengamalkannya secara utuh (kaffah), maka keberadaan umat Islam akan benar-benar menjadi rahmat bagi lingkungannya (rahmatan li al-lil'alamin). 
Di antara nilai-nilai Islam yang menghargai pluralis multikultural adalah:

1. Konsep kesamaan (al-sawiyah) yang memandang manusia pada dasarnya sama derajatnya. Satu-satunya pembedaan kualitatif dalam pandangan Islam adalah ketaqwaan. Pada waktu melakukan ibadah haji terakhir Nabi Muhammad SAW membuat pernyataan dengan etika global dalam sebuah hadis Diriwayatkan oleh AlAdda' bin Khalid dalam Al- Thabari's alMu'jam al-Kabir: "Wahai umat manusia, semua orang berasal dari Adam sedang Adam dari ekstrak tanah. Orang Arab tidak lebih mulia daripada non-Arab, orang kulit putih tidak lebih mulia daripada orang kulit hitam, kecuali karena kelebihan ketaqwaannya" (HR. Abu Hurairah).

Hal ini membuktikan bahwa Islam tidak membeda-bedakan perlakuan terhadap seseorang berdasarkan ras, agama, etnis, suku, ataupun kebangsaannya, hanya ketaqwaan seseoranglah yang membedakannya di hadapan Sang Pencipta.

2. Konsep keadilan (al-'adalah) yang membongkar budaya nepotisme dan sikapsikap korup, baik dalam politik, ekonomi, hukum, hak dan kewajiban, bahkan dalam praktek-praktek keagamaan. Al-Quran memerintahkan agar berlaku adil terhadap siapapun,

wur öNà6"ZtBì ôft ãb\$t «oYx@ C BQöqs\% \# n?tã wr\& (\#qä9ï :ès? 4 (\#qä9ï ôã\$\# uqèd Ü>t $\varnothing \% \& 3$ uqø)-G=̈9 (

“Jangan sampai kebencian terhadap suatu kaum itu mendorong untuk tidak berlaku adil (Q.S An-Nisa':58),

Adil harus dilakukan terhadap diri sendiri, keluarga, kelompok, dan juga terhadap lawan.

3. Konsep kebebasan atau kemerdekaan (alhurriyah) yang memandang semua manusia pada hakikatnya hamba Tuhan saja, sama sekali bukan hamba sesama manusia.
Berakar dari konsep ini, maka manusia dalam pandangan Islam mempunyai kemerdekaan dalam memilih profesi, memilih wilayah hidup, bahkan dalam menentukan pilihan agamapun tidak dapat dipaksa seperti tercantum dalam al-Quran surat AlBaqarah:256.

Iw on\#t ø.Î) Îû Êuiil̈e\$!\$ ( s\%tû"üt6"? ß ô (c) 9 \$\# z ÏB Äcóxöø9\$ 4 'yJ sù

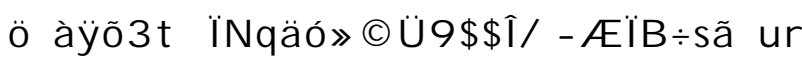
«!\$\$i/ Ï s)sù y7|iôj tGó \$\# Íouró ãèø9 \$\$î/ 4 s+øOâqø9\$ w tP\$|Ál̈ÿR\$\# \$olm; 3 a! \$\#ur ì̀ Ïÿx îlî̂=tæÇËÎÏE

Tidak ada paksaan untuk (memasuki) agama (Islam); Sesungguhnya telah jelas jalan yang benar daripada jalan yang sesat. karena itu Barangsiapa yang ingkar kepada Thaghut dan beriman kepada Allah, Maka Sesungguhnya ia telah berpegang kepada buhul tali yang Amat kuat yang tidak akan putus. dan Allah Maha mendengar lagi Maha mengetahui.

4. Konsep toleransi (tasamuh) yang merupakan kemampuan untuk menghormati sifat dasar, keyakinan, dan perilaku yang dimiliki oleh orang lain. Tasamuh juga dipahami sebagai sifat atau sikap menghargai, membiarkan, atau membolehkan pendirian (pandangan) orang lain yang bertentangan dengan pandangan kita. Alwi Shihab, 1998:41)

Toleransi dalam pergaulan hidup antar umat beragama bukanlah toleransi dalam masalah-masalah keagamaan, melainkan perwujudan sikap keberagamaan pemeluk suatu agama dalam pergaulan hidup antara orang yang tidak seagama, dalam masalah-masalah kemasyarakatan atau kemaslahatan umum.

Ternyata ajaran Islam sangat sejalan, bahkan mendukung prinsip multikultural yang berkenaan dengan kebinekaan dalam kesatuan dan kebersamaan. Keanekaraman ras, suku bangsa dan bahasa adalah sebuah kodrat Ilahi. 
Manusia harus pintar dalam mensyukuri nikmat Allah yang sangat besar ini. Allah SWT. menegaskan agar dengan adanya berbagai suku dan bangsa agar manusia saling mengenal. Allah tidak membedakan yang satu dengan yang lainnya kecuali karena perbedaan ketakwaan. Di samping itu Islam dengan jelas menyatakan bahwa tidak ada paksaan dalam memilih agama. Maka terlihat betapa Islam mengakui adanya kemajemukan dalam kehidupan. Dan untuk mendamaikan keberbedaan ini adalah melalui toleransi. Menghargai keberadaannya, menghormati aktivitasnya akan tetapi umat Islam harus tetap yakin bahwa Islam adalah jalan yang paling benar. Islam mengakui pluralitas dan multikultur adalah realitas sosial.

Prinsip multikultural dalam Islam bukanlah untuk mengaburkan nilai-nilai yang ada. seperti norma agama, baik-buruk, haq-bathil, benarsalah dan lain sebagainya. Di samping itu dalam Islam dari nilai-nilai agamalah konstruksi perdaban terbentuk dan bukan budaya yang membentuk konstruksi agama. inilah yang membedakan antara Islam dan Barat.

Poin terpenting dalam prinsip multikulturalis dalam Islam adalah dianjurkannya bersikap toleransi hanya pada masalah sosial kemasyarakatan dan tidak masuk ke ranah aqidah dan ibadah. Karena dalam pandangan Islam satu-satunya agama yang diakui kebenarannya di sisi Allah hanyalah Islam.

Dalam catatan sejarah, kemajemukan dan pluralitas tumbuh dan berkembang dengan baik pada periode Madinah. Di Medinah Rasullah meletakkan dasar-dasar kehidupan yang majemuk di mana hidup tiga penganut agama samawi yaitu orang-orang Islam, Nasrani dan Yahudi. Nabi mengikat kerukunan dan toleransi di antara penganut ketiga agama serta suku-suku yang ada dengan tali perjanjian yang menjadi kesepakatan bersama, yang dikenal dengan Piagam Medinah. Nabi pun bertindak secara tegas kepada siapapun yang mengingkari dan melanggar kesepakatan hidup bersama seperti yang tertuang dalam Piagam Medinah. Karena keteladanan yang diberikan oleh Rasul dalam membangun kerukunan hidup bersama maka semua masyarakat mengikutinya dan tunduk pada kesepakatan yang dibuat. Di sinilah kemudian lahir kehidupan mayarakat yang berperadaban tinggi dan menjadi contoh model bangunan masyarakat yang pluralistik.

Berdasarkan keterangan di atas dapat dipahami bahwa Islam sebagai agama rahmatan li al-'alamin sudah mengembangkan prinsipprinsip multikulturalisme jauh sebelum wacana multikulturalisme itu muncul. Islam adalah agama yang sempurna, di dalamnya ada aturanaturan tentang urusan dunia dan akhirat. Di antaranya adalah terdapat dasar-dasar peraturan untuk hidup berdampingan secara damai dengan siapapun.

\section{PERANAN PENDIDIKAN AGAMA ISLAM DALAM PENGEMBANGAN NILAI-NILAI MULTIKULTURAL}

Salah satu usaha yang harus dilakukan untuk menanamkan nilai-nilai multikulturalisme adalah melalui pendidikan multikultural, yang membuat masyarakat kita mampu menerima perbedaan dan hidup dengan nyaman bahkan mampu menjalankan perannya sebagai warga negara di negara kita yang multikultural ini.

Maka dalam hal ini Pendidikan Agama Islam dapat memberikan kontribusi dalam mewarnai kehidupan masyarakat yang majemuk ini. Pendidikan Islam diharapkan mampu menumbuhkan kesadaran pluralismmultikultural sebagai upaya untuk memahami perbedaan yang ada pada sesama manusia, apa pun jenis perbedaannya, serta bagaimana agar perbedaan tersebut diterima sebagai hal yang alamiah (natural, sunnatullah) dan tidak menimbulkan tindakan diskriminatif, sebagai buah dari pola perilaku dan sikap hidup yang mencerminkan iri hati, dengki dan buruk sangka.

Nilai-nilai kedamaian dan kebersamaan, yang dalam konteks ini terkandung dalam ajaran Islam tersebut perlu diungkap agar bisa diinternalisasikan oleh peserta didik dalam kehidupan sehari-hari. Pendidikan Agama Islam yang disajikan di sekolah mencerminkan nuansa egalitarian sehingga peserta didik mampu bersikap saling menghormati antar sesamanya atau kepada yang berlainan suku, ras, agama maupun bahasa. 
Ngainun Naim dan Amad Sauqi (Ngainun Naim, Achmad Sauqi, 2008: 53-54) menawarkan konsep pendidikan Islam pluralismultikultural yang dikembangkan dengan: pertama, pendidikan Islam pluralismultikultural merupakan pendidikan yang menghargai dan merangkul segala bentuk keragaman. Dengan demikian diharapkan akan tumbuh kearifan dalam melihat segala bentuk keragaman yang ada.

Kedua, pendidikan Islam pluralismultikultural merupakan sebuah usaha sistematis untuk membangun pengertian, pemahaman dan kesadaran peserta didik terhadap realitas yang pluralis-multikultural. Hal ini perlu dilakukan, karena tanpa adanya usaha secara sistematis, realitas keragaman akan dipahami secara sporadis, fragmentaris, atau bahkan memunculkan ekslusivitas yang ekstrim.

Ketiga, pendidikan Islam pluralmultikultural tidak memaksa atau menolak peserta didik karena persoalan identitas suku, agama, ras atau golongan. Mereka yang berasal dari beragam perbedaan harus diposisikan secara setara, egaliter, serta diberikan media yang tepat untuk mengapresiasi karakteristik yang mereka miliki. Dalam kondisi semacam ini tidak ada yang lebih unggul antara satu peserta didik dengan pserta didik yang lain. Masingmasing memiliki posisi yang sama dan harus memperoleh perlakuan yang sama pula.

Keempat, pendidikan Islam pluralismultikultural memberikan kesempatan untuk tumbuh dan berkembangnya sense of self kepada setiap peserta didik. Ini penting untuk membangun kepercayaan diri, terutama bagi peserta didik yang berasal dari kalangan ekonomi kurang beruntung atau kelompok yang relatif terisolasi.

Dalam rangka pendidikan multikultural peserta didik perlu: Departemen Agama RI, 2009:21-25)

1. Diperkenalkan berbagai bentuk cara berpikir dan bertindak yang akan mempengaruhi bentuk dan wujud hubungan antar kultur dan antar umat beragama. Kemudian peserta didik diajak menetapkan manakah cara yang harus dilakukan. Bentuk dan hubungan tersebut antara lain:

a. Konflik dan pertentangan

Konflik atau pertentangan merupakan suasana hubungan di mana mereka yang berbeda agama, budaya, baik secara pribadi maupun secara kelompok saling bertentangan. Hal-hal yang berbeda dalam masing-masing agama dipertentangkan sedangkan persamaanpersamaan cenderung diabaikan.

b. Toleransi

Konflik yang disadari bersama dapat menjadi titikn tolak tumbuhnya toleransi. Sikap toleran adalah sikap yang tidak menolak perbedaan-perbedaan. Toleransi tidak cukup sebatas kesadaran semata, akan tetapi harus diiringi dengan tindakan nyata atau implementasi di tengah-tengah kehidupan bermasyarakat.

c. Dialog

Bila toleransi dipandang sebagai institusi yang dapat menyelesaikan konflik meskipun dengan bahan-bahan komunikasi yang masih terbatas, maka dialog merupakan institusi pertukaran inspirasi dan aspirasi. Dengan cara ini, nilai-nilai luhur masing-masing agama akan dapat dieksplorasi dan menjadi kekayaan bersama, serta menjadi sumber inspirasi dalam kehidupan budaya, kemasyarakatan, dan keagamaan.

d. Persaudaraan sejati

Persaudaraan sejati merupakan suasana yang dibangun berdasarkan toleransi dan dialog. Situasi ini terwujud manakala orang telah dapat merasakan manfaat dari nilai-nilai luhur masing-masing agama dan kebudayaan dalam membangun kehidupan bersama. Selain itu nilai-nilai luhur tersebut telah menjadi milik bersama dan dapat dijadikan dasar dalam bekerja sama.

2. Dalam dialog peserta didik dibimbing dan diperkenalkan cara-cara menyelesaikan masalah sosial, agama dan akibat keaneka- 
ragaman pada masyarakat mutikultural dengan cara:

a. Mengintegrasikan unsur-unsur sosial seperti ras, suku dan agama. Perbedaan ras, suku dan agama memang menyimpan potensi konflik yang sangat tajam, oleh sebab itu keadaan ras, suku dan agama yang berbeda-beda sedapat mungkin diintegrasikan untuk diarahkan pada kepentingan Nasional. Upaya pengintegrasian dapat pula dilakukan melalui kegiatan organisasi. Misalnya forum komunikasi kepemudaan, organisasi massa, OSIS, karang taruna, KNPI dan lain sebagainya. Forum-forum seperti ini dapat menjadi wadah kumunikasi, pertukaran nilai, saling memahami dan kerjasama para anggota yang bersifat universal melampaui batasbatas ras, suku, agama, dan asala daerah.

b. Mengembangkan budaya Nasional yang bersumber dari budaya daerah.

Sebagai suatau bangsa, Indonesia harus memiliki suatu sistem budaya nasional. Budaya ini diangkat dari kebudayaan daerah yang dianggap baik dan dapat diterima oleh berbagai elemen masyarakat. Proses kelahiran negara dan bangsa Indonesia didahului dengan adanya budaya-budaya daerah. Budayabudaya puncak daerah diangkat menjadi budaya nasional, seperti pakaian nasional, kesenian nasional dan lain-lain.

c. Mengembangkan sikap tenggang rasa antar unsur sosial

Kesadaran akan perbedaan dan kesediaan untuk bekerja sama menuju keutuhan dan persatuan bangsa akan dapat tumbuh secara baik bila didasarkan pada sikap tenggang rasa antar komponen masyarakat. Pada dasarnya sikap tenggang rasa dapat meredam konflik antar individu dalam masyarakat. Sikap tenggang rasa ini dapat dibangun melalui wawasan yang luas tentang karakteristik suku-suku bangsa maupun agama-agama yang ada di Indonesia. d. Mengembangkan wawasan kebangsaan

Akhir-akhir ini pembinaan rasa nasionalisme kepada peserta didik dirasakan sangat rendah. Hal ini diakibatkan oleh desakan muatanmuatan pelajaran yang ada di sekolah. Akibatnya, wawasan kebangsaan menjadi menipis atau mengecil dan berakibat pada hilangnya kesadaran akan nilai-nilai kebersamaan dan kekeluargaan yang amat dibutuhkan dalam membangun sebuah negara. Rasa nasionalisme dapat dibangun melalui pengetahuan tentang wilayah dan unsurunsur sosial yang ada di Indonesia. Orang yang memiliki wawasan kebangsaan akan mampu memberikan darma baktinya pada bangsa dan negara. Dengan demikian terbangunlah sikap nasionalisme dan patriotisme.

e. Meletakkan landasan tentang HAM

Sikap toleransi akan mendorong setiap orang untuk dapat memahami dan menghargai hak asasi setiap individu dalam kehidupan bermasyarakat. Hal ini berarti setiap orang dapat hidup dalam perbedaan dengan terus menerus mengembangkan sikap saling menghormati dan menghargai. Melalui pengembangan hak asasi manusia, setiap individu akan menyadari bahwa orang lain di luar dirinya memiliki hak asasi yang sama dengan dirinya dan tidak boleh diganggu gugat oleh siapapun termasuk negara.

f. Membangun sikap toleransi antar umat beragama

Toleransi beragama merupakan kesediaan menerima keanekaragaman ajaran agama yang dianut. Hal ini dapat terjadi karena keberadaan suatu agama diakui dan dihormati oleh pihak lain. Pengakuan tersebut tidak terbatas pada persamaan derajat, baik dalam tataran kenegaraan, kemasyarakatan, maupun di hadapan Tuhan Yang Maha Esa, tetapi juga perbedaan-perbedaan dalam cara penghayatan dan peribadatannya yang 
sesuai dengan dasar kemanusiaan yang adil dan beradab.

Dalam rangka menumbuhkan dan mengembangkan toleransi antar umat beragama, peserta didik harus menghindari atau menjauhi beberapa sikap, yaitu:

1. Fanatisme yang berlebihan, yaitu sikap yang tidak bersedia menghargai pemeluk agama lain, atau bahkan memusuhinya. Peserta didik harus benar-benar meyakini (tidak boleh ragu-ragu) terhadap agama yang dianutnya, tanpa membuat pandangan dan sikap keagamaan menjadi sempalan yang pada akhirnya melahirkan sikap meremehkan dan melecehkan keyakinan pemeluk agama lain,

2. Tidak mencampuradukkan ajaran suatu agama/kepercayaan dengan agama/ kepercayaan yang lain. Dalam hal ini kemurnian dan keunikan masing-masing agama/kepercayaan harus tetap terjaga dan terpelihara. Dengan demikian tidak ada pembenaran pada upaya mencampuradukkan satu agama/ kepercayaan dengan agama dan kepercayaan lain.

3. Sikap acuh tak acuh terhadap agama/kepercayaan lain. Toleransi beragama menghendaki kejujuran dan kebesaran jiwa dari-masing-masing pemeluk agama. Bangsa Indonesia beruntung telah mempunyai tradisi yang baik mengenai toleransi atau kerukunan hidup beragama. Tradisi yang baik ini hendaknya dilanjutkan secara berkesinambungan sehingga terbina kerukunan hidup antar umat beragama. Pada sisi lain pemerintah haruslah memberikan jaminan kebebasan hidup beragama bagi seluruh bangsa Indonesia.

Keragaman adalah anugerah Ilahi yang harus dirangkai menjadi simfoni keindahan yang harmonis. Mustahil kita hidup dalam satu kesatuan yang seragam. Peserta didik harus dibuka mata dan wawasannya untuk melihat sekian perbedaan yang ada di sekitarnya, di mana masyarakat Indonesia merupakan masyarakat yang heterogen dan plural. Paling tidak heterogenitas dan pluralitas masyarakat itu dapat dilihat dari eksistensi keragaman suku (etnis), ras, agama, dan budaya. Inilah realitas bangsa yang multikultural dan multireligious. Kekayaan ini harus dijaga menjadi keragaman di bawah semangat kebersamaan, bukan penyatuan.

Kesadaran akan keragaman tidak dapat diajarkan, akan tetapi kesadaran ini akan lahir melalui proses humanisasi. Proses ini berupaya menuntun seseorang untuk menginternalisasikan nilai-nilai budaya yang hidup dan yang akan dikembangkan sehingga ia menjadi manusia yang bersusila, beradab dan berkepribadian (civilized). Dengan demikian kesadaran akan keragaman tidak perlu diwujudkan dalam bentuk mata pelajaran di sekolah. Nilai-nilai keragaman harus diperkenalkan dan ditanamkan kepada peserta didik. Hal ini dapat dilakukan melalui proses integrasi nilai-nilai tersebut ke dalam mata pelajaran- mata pelajaran yang relevan. (Departemen Agama RI, 2009:12)

Maka strategi ini akan berhasil guna dan berdaya guna jika diikuti dengan keteladanan (modelling) dan pembiasaan dalam kehidupan sosial di sekolah. Jadi diperlukan adanya educational sphere yang kondusif bagi tumbuh dan berkembangnya kesadaran akan keragaman di sekolah.

Di samping itu pendidikan multikultural dapat diimplementasikan tidak hanya melalui pendidikan formal namun juga dapat diimplementasikan dalam kehidupan masyarakat maupun dalam keluarga. Dalam pendidikan formal pendidikan multikultural ini dapat diintegrasikan dalam sistem pendidikan melalui kurikulum mulai Pendidikan Usia Dini, SD, SLTP, SMU maupun Perguruan Tinggi.

Di samping itu, Pendidikan Multikultural ini tidak harus dirancang khusus sebagai muatan substansi tersendiri, namun dapat diintegrasikan dalam kurikulum yang sudah ada tentu saja melalui bahan ajar 
atau model pembelajaran yang paling memungkinkan diterapkannya pendidikan multikultural ini. Di Perguruan Tinggi misalnya, dari segi substansi, pendidikan multikultural ini dapat dinitegrasikan dalam kurikulum yang berperspektif multikultural, misalnya melalui mata kuliah umum seperti Kewarganegaraan, ISBD, Agama dan Bahasa. Demikian juga pada tingkat sekolah Usia Dini dapat diintegrasikan dalam kurikulum pendidikan misalnya dalam Out Bond Program, dan pada tingkat SD, SLTP maupun Sekolah menengah pendidikan multikultural ini dapat diintegrasikan dalam mata pelajaran seperti PPKn, Agama, Sosiologi dan Antropologi, dan dapat melalui model pembelajaran yang lain seperti melalui kelompok diskusi, kegiatan ekstrakurikuler dan sebagainya.

Lewat penanaman semangat multikulturalisme di sekolah-sekolah, akan menjadi medium pelatihan dan penyadaran bagi peserta didik dan generasi muda untuk menerima perbedaan budaya, agama, ras, etnis, dan kebutuhan di antara sesama dan mau hidup bersama secara damai. Agar proses ini berjalan sesuai harapan, maka pendidikan multikultural perlu disosialisasikan dan didiseminasikan melalui lembaga pendidikan. Apalagi, paradigma multikultural secara implisit juga menjadi salah satu concern dari Pasal 4 UU N0. 20 Tahun 2003 Sistem Pendidikan Nasional. Dalam pasal itu dijelaskan, bahwa pendidikan diselenggarakan secara demokratis, tidak diskriminatif dengan menjunjung tinggi HAM, nilai keagamaan, nilai kultural dan kemajemukan bangsa.

Di samping itu dalam membangun pemahaman nilai-nilai keberagaman kepada siswa yang di sekolah, guru mempunyai posisi penting dalam mengimplementasikan nilai-nilai keberagaman di sekolah. Adapun peran guru di sini, meliputi; pertama, seorang guru/dosen harus mampu bersikap demokratis, baik dalam sikap maupun perkataannya tidak diskriminatif. Kedua, guru/dosen seharusnya mempunyai kepedulian yang tinggi terhadap kejadian- kejadian tertentu yang ada hubungannya dengan agama. Misalnya, ketika terjadi bom Bali (2003), maka seorang guru yang berwawasan multikultural harus mampu menjelaskan keprihatinannya terhadap peristiwa tersebut. Ketiga, guru/dosen seharusnya menjelaskan bahwa inti dari ajaran agama adalah menciptakan kedamaian dan kesejahteraan bagi seluruh ummat manusia, maka pemboman, invasi militer, dan segala bentuk kekerasan adalah sesuatu yang dilarang oleh agama. Keempat, guru/ dosen mampu memberikan pemahaman tentang pentingnya dialog dan musyawarah dalam menyelesaikan berbagai permasalahan yang berkaitan dengan keragaman budaya, etnis, dan agama.

\section{SIMPULAN}

Multilukturalisme merupakan suatu yang sangat penting dimiliki oleh warga negara Indonesia karena Indonesia merupakan bangsa yang majemuk terdiri dari bermacam macam suku, ras, budaya, dan agama. Agaknya menarik perhatian kita untuk berpikir ulang tentang peran agama, lebih khusus pendidikan agama Islam dalam mewarnai kehidupan masyarakat yang majemuk ini. Pendidikan Islam mampu menumbuhkan kesadaran pluralis-multikulturalis sebagai upaya untuk memahami perbedaan yang ada pada sesama manusia, apa pun jenis perbedaannya.

Adapun yang membedakan prinsip multikultur dalam pandangan Islam dan multikuturalisme dalam pandangan Barat adalah dalam pandangan Islam agama bukan masuk ke dalam ranah budaya, karena agama diturunkan oleh Allah dalam rangka membimbing kehidupan manusia. Sedangkan dalam multikulturalisme di Barat memasukkan agama ke dalam budaya. Maka dalam Islam tidak dikenal toleransi dalam aqidah dan ibadah.

\section{DAFTAR RUJUKAN}


Abdul Munir Mulkhan, 2005. Kesalehan Multikultural, Jakarta: Pusat Studi Agama dan Peradaban Muhammadiyah

Ain al-Rafiq Dawam, 2003. Emoh Sekolah, Yogyakarta: Inspeal Ahimsa Karya Press

Alwi Shihab, 1998. Islam Inklusif, Menuju Sikap Terbuka dalam Beragama, Bandung: Mizan, cet. ke-3,

Choirul Fuad Yusuf, 2006. Edukasi Jurnal Penelitian Pendidikan dan Keagamaan, Jakarta: Badan Litbang dan Diklat Depag RI

Choirul Mahfud, 2006. Pendidikan Multikultural, Yogyakarta: Pustaka Pelajar

Departemen Agama RI, 2009. Pengembangan Pendidikan Agama Islam Berbasis Multikultural, Jakarta: Direktorat Pendidikan Agama Islam pada Sekolah Dirjen Pendis

H.A Dardi Hasyim, Yudi Hartono. Pendidikan Multikultural di Sekolah. Surakarta: UPT penerbitan dan percetakan UNS

H.A.R Tilaar, 2003. Kekusaan Dan Pendidikan Suatu Tinjauan Dan Persepektif Studi Kultural, IndonesiaTera

M. Amin Abdullah, 2005. Pendidikan Agama Era Multikultural Multireligius, Jakarta: Pusat Studi Agama dan Peradaban Muhammadiyah

Mashadi Imron, 2009. Pendidikan Agama Islam Dalam Persepektif Multikulturalisme, Jakarta: Balai Litbang Agama
Nanih Mahendrawati dan Ahmad Syafe'i, 2001. Pengembangan Masyarakat Islam: dari Ideologi, Strategi Sampai Tradisi, Bandung: Remaja Rosda Karya

Ngainun Naim, Achmad Sauqi, 2008. Pendidikan Multikultural, Konsep dan Aplikasi, Jogjakarta: al-Ruzz Media Group

Said Agil Husin al-Munawar, 2003. Aktualisasi Nilai-nilai Qurani dalam Sistem Pendidikan Islam, Jakarta: Ciputat Press 